\title{
Integral Calculus Learning Using Problem Based Learning Model Assisted by Hypermedia-Based E-Book
}

\author{
Awaludin $^{1}$, Basuki Wibawa ${ }^{2}$, Murni Winarsih ${ }^{3}$ \\ ${ }^{1}$ Deparetemen Of Mathematics Education, Halu Oleo University, Kendari \\ 2,3 Lecturer Post Graduate Education Technology, Universitas Negeri Jakarta, Jakarta \\ e-mail: awaludinrahman2019@gmail.com, bwibawa@unj.ac.id,mwinarsih@unj.ac.id
}

\begin{abstract}
The focus of this study is the effectiveness of the Problem Based Learning (PBL) model assisted by hypermedia-based e-books on the results of integral calculus learning. The objectives of the study are (1) to describe the students' learning outcomes of integral calculus which are taught through problem-based learning model with the help of a hypermedia-based e-book, and (2) to find out the effectiveness of the Problem Based Learning model with the help of a Hypermedia-Based e-book on integral calculus learning outcomes. This research employed an experiment with a posttest only control design. The study population was all students from the Department of Mathematics Education, Halu Oleo University in the 2017-2018 academic year. The study sample consisted of 60 students distributed equally in two classes namely the experimental class (30) and the control class (30). The Problem Based Learning model with the help of a hypermedia-based e-book was applied in the experimental class while the traditional learning model with the help of printed teaching materials was applied in the control class. The PBL learning model steps consist of (1) presenting contextual problems, (2) forming cooperative groups, (3) analyzing problems cooperatively, (4) presenting the results of group discussions, (5) reflections. Data were collected using the test of integral calculus learning. Then the data were analyzed descriptively and inferentially. The descriptive analysis included the mean value, variance, and standard deviation, while the inferential analysis included the data normality test, the data homogeneity test, and the average difference test. The results showed that the students' integral calculus learning outcomes taught with Problem Based Learning model was categorized well, and the $P B L$ learning model effectively improved the integral calculus learning outcomes.
\end{abstract}

Keyword: Problem Based Learning; E-book; Hypermedia; Learning Achievement

\section{Introduction}

Integral calculus is a subject that must be mastered by every student majoring in mathematics at Halu Oleo University. This course is skill-related and is grouped with other subjects such as multivariable calculus, differential equations, mathematical statistics, initial value problems, and boundary conditions. However, the problems encountered so far in learning calculus are (1) low participation of students in asking, answering questions lecturer, express ideas, (2) difficulties in answering practice questions, (3) low mastery of basic calculus concepts, (4) limited ability to create problem-solving models, (5) lack of problem-solving abilities for contextual problems, (6) low score in integral calculus courses (50.3 in 2015 and 53.2 in 2016). Yet in calculus class, students are expected to be able to actively participate, solve practice questions, have knowledge and thinking skills that can be used in problemsolving for contextual problems, able to make problem-solving models, and have a minimum Integral Calculus learning outcome value $>65$. The intended knowledge includes aspects of retention (remembering facts, concepts, and symbols), understanding integral calculus concepts, being able to apply concepts, principles and procedures in problem-solving, analytical thinking, and being creative in solving problems.

Integral calculus learning outcomes can be measured by several indicators namely the ability to remember, understand, apply, analyze, evaluate, and creativity. Concerning the ability to remember, students are expected to remember mathematical facts or symbols used, remember concepts or definitions related to indeterminate integrals, specific integrals, area,

\footnotetext{
* Corresponding author.

Received 2 January 2019; Accepted 15 June 2020; Available online 20 June 2020

(C) 2020 JPI. All Rights Reserved
} 
and volume of rotating objects. Understanding ability is related to the ability to interpret contextual problems into mathematical models and to interpret images or graphics. Furthermore, students are expected to apply mathematical concepts, principles, and procedures in problem-solving, for example, the use of procedures for calculating the area under a curve using polygons outside or inside. Furthermore, analytical skills refer to the ability to describe various interrelated concepts in a problem, then unite, make connections between concepts, and use these concepts to solve problems appropriately. For example, if students are given two intersecting curves, they can determine the area between the two curves. Then students are expected to be able to evaluate whether the problem-solving strategies used are correct. Student creativity is related to the smoothness of students in solving problems, the ability to use various techniques in problem-solving. For example, students can use the ring method or the tube shell method to determine the volume of a rotating object.

The low participation and low integral calculus achievements were caused by the learning model used which was still teacher-centered. Therefore, to solve these problems, the use of an instructional model is needed. An instructional model is a conceptual framework that describes a learning system that is used as the basis for implementing learning so that learning objectives can be achieved. This means that the learning model is related to the design of learning materials, and learning strategies that will be used in learning. One of the models that can be used to achieve these objectives is problem-based learning models. Problem Based Learning model is a learning model that provides opportunities for students to actively participate in learning through cooperation. Students are trained to construct concepts and principles and can then create mathematical models based on contextual problems.

According to Barbara, et al (2001), problem-based learning is used to motivate students to identify and find concepts needed to solve problems. Moreover, it facilitates students to work in small groups to communicate and share information. Capabilities expected in the PBL are (1) think critically and analytically to solve problems around the world, (2) find, evaluate and use appropriate learning resources, (3) work in teams in small groups, (4) demonstrate effective communicative abilities in the form of verbal and writing skills, (5) using knowledge and intellectual skills gained from universal problems to become continuous learning.

According to Boud \& Feletti, (1997 as cited in Barbara, 2001), the process of PBL includes (1) giving a problem in the form of cases, research problems for students to work in groups by organizing ideas and prior knowledge to identify given problems, (2) discussing by asking questions to illustrate the problem that is not understood. The problem raised is recorded by each group member and becomes the focus of discussion. Students are encouraged to define what is known and what is not known, and (3) the student selects problems to be discussed in class and determine what resources are needed to resolve the problem, (4) students are encouraged to summarize their knowledge and connect concepts new concepts to the old.

Barrows and Myers state that the PBL model has five main areas. They are (1) introducing the PBL concept and forming a learning environment, (2) introducing problem configurations and assignment assignments, (3) analyzing information collected critically, (4) getting solutions to problems, and (5) abstracting acquired knowledge and self-evaluation (Savery \& Duffy, 1995). Meanwhile, according to Phungsuk, Viriyavejakul, and Ratanaolarn (2017), Problem Based Learning is a student-centered pedagogy in which students learn about the subject matter by emphasizing the discovery of solutions to open problems. Problem Based Learning is a method of learning to improve students' problem-solving skills through interaction with others. Based on these opinions, Problem Based Learning is a studentcentered learning model that aims to practice the ability to understand concepts, communication, and problem-solving of students where the teacher presents contextual problems to be cooperatively solved. Stages of Problem Based Learning include (1) presentation of contextual problems, (2) formation of cooperative groups, (3) problem analysis cooperatively, (4) presentation of the results of group discussions, and (5) Reflection.

The implementation of PBL concepts in learning has proven its effectiveness. This is in line with the findings of Yew \& Goh (2016) that the stages in PBL affect the students' learning outcomes. Moreover, Balan, Yuen, \& Mehrtash, (2019) stated that applying PBL as a learning 
method can give satisfaction to students in learning. Kazemi \& Ghoraishi, (2012) state that the PBL method is more effective than traditional methods in learning mathematics Ahmad \& Bayat (2012) argue that there are significant differences in the average learning outcomes (performance) in statistical learning that is taught by $\mathrm{PBL}$ with conventional learning. According to Izzati, Ahmad, \& Abu (2010), PBL is better in improving mathematical communication skills. Tarmizi, Tarmizi, Lojini, and Mukhtar (2010) argue the problem-based learning strategy has implications in learning specifically in improving students' thinking and communication skills.

Furthermore, the results of research by Ari and Katranci (2014) show that Problem Based Learning can be applied in mathematics learning because it can improve students' thinking skills, increase student participation in learning, attention, and desire of students to learn and look for problem-solving. This is in line with the opinion of Sinprakob and Songkram (2015) that Problem Based Learning can be used as a strategy to encourage students to develop critical thinking skills and apply their knowledge for problem-solving. Critical thinking skills that can be developed through Problem Based Learning are the ability to understand contextual problems, analyze problems, evaluate strategies used in problem-solving. Understanding problems is a basic element in solving mathematical problems. Furthermore, students will do a description of certain parts of the problem and look for the relationship so students can make a mathematical model of the problem. Then in the evaluation step students ensure that the strategies used in solving the problem are correct.

The results of previous studies regarding the application of PBL in learning indicate that PBL influences the learning process and outcomes. The learning process is characterized by increased student's participation, attention, and desire to learn and look for problem-solving. It leads to student's satisfaction with learning. Whereas in terms of learning outcomes, it shows that PBL can affect the ability to think critically and improve mathematics learning outcomes.

Besides the use of learning models, to improve students' learning outcomes, learning materials are needed. Learning materials are all forms of learning resources both in print and non-print forms that can be used as a source of information so that effective and efficient interaction occurs between a teacher and students to achieve learning goals. Learning materials that can be used in calculus class is material such as hypermedia-based ebooks. The pedagogical aspect of the use of hypermedia-based e-Books in calculus class is that the ebook material is more interactive. Through e-Book, students can give play multiple media materials such as animation and video. Animation and video enable students to easily understand the material being studied. It also helps to review the material repeatedly if the material is considered important and if a concept must be mastered. Moreover, Hypermediabased e-Books facilitate students to learn the material in groups. Video enables students and teachers to observe academic experiences and reflect on them in class and can gather information (Pérez-torregrosa, Díaz-martín, \& Ibáñez-cubillas, 2017). Students who have limitations in remembering the concepts and procedures for solving problems presented through lecturers' explanations can then learn information or concepts through animation or learning videos in the Hypermedia based e-Book. The presentation of material in the form of animation can increase student motivation in learning. This is in line with the opinion of Steinke, Huk, \& Floto (2004) that the integration of three-dimensional animation models in education can increase user motivation. The existence of animated media in learning mathematics is very important because students will see a visualization of an object that is abstract. In other words, through animation media, it is easy for students to understand mathematical concepts.

According to Moos \& Marroquin (2010), hypermedia can present information from various directions both through text, images, animations, and videos so students are motivated to learn. Through this hypermedia-based e-Book, students can learn anywhere and anytime because it can be accessed by a cell phone or notebook. This is in line with the opinion of Taub, Azevedo, Bouchet, \& Khosravifar, (2014) that students have self-regulated learning when using hypermedia -based learning resources. According to Hmelo-Silver \& Azevedo, (2009), Winne \& Nesbit, (2010), and Zimmerman, (2002) in (Paans, Molenaar, Segers, \& Verhoeven, 2018) self-regulated learning is the ability of a student to use cognitive, metacognitive and motivation to achieve learning goals. 
Furthermore, Gerjets (2017) states that learning material presented in the form of hypermedia can stimulate active and multi-perspective learning because it encourages students to explore hyperlinks interactively and facilitates students to build learning independence. When students explore hyperlinks, students learn the material through images, animation, video, and other forms of text. This certainly provides an opportunity for students to easily comprehend the material. Students can learn repeatedly so that concepts can be stored in cognitive structures.

Electronic books (e-Books) can facilitate children to learn. As stated by Gonźalez, Guzman, Dormido, \& Berenguel, (2013, p. 151) that e-Books can be read anywhere with compatible equipment. It can enrich the text by connecting multimedia elements, allowing it to provide annotations and comments on e-Books. Furthermore, Monica, Gorghiu, Bîzoi, \& Maria, (2011) state that e-books provide convenience for students compared to using printed books. E-books are an easier way of finding and reading digital information that is not tied to the place. The material is interactive and includes links to images, graphics, tables, videos.

PBL models in the integrated calculus course assisted by the Hypermedia e-Book are designed by providing examples of questions and exercises that are tailored to the development of students and each practice question is provided with an answer key created in an animation. The exercises are given ranging from simple to complex and adapted to the concepts that have been learned. This makes it easy for students to understand the answers of each practice question. To facilitate students' understanding of technical terms in the field of scientific calculus, a glossary is provided in the e-book. Images, animations, and videos in e-Books are designed to be interesting so that students are motivated to learn through eBooks. The link facility in the e-Book is made to enable the students to link between the materials being studied with the previous material.

Images and animations in e-Book content are a visualization of abstract concepts because the study material in integral calculus is abstract. It requires semi-abstract or concrete media so that students can understand the material better. Students who have limitations in remembering the concepts and procedures for solving problems presented through lecturer explanation can then learn information or concepts through animation or learning videos contained in the Hypermedia-based e-Book content. According to Moos \& Marroquin, (2010), Hypermedia can present information from various directions both through text, images, animations, and videos so students are motivated to learn.

Hypermedia-based e-Book content is developed based on needs analysis, learning objectives, and assessment tools that have been developed. This means that in the pedagogical aspect of implementing learning it is based on an analysis of the behavior and characteristics of students, learning objectives, and learning assessment tools. These are done to ensure that the expected students' competency in the field of calculus can be achieved. The relationship between educators and students when using hypermedia-based e-Books will be more dynamic and the information presented is multi-directional. Students can learn or read the learning material contained in e-Books. Learners can learn the material in the e-Book without depending on the educator.

Using Hypermedia-based e-Books as learning material in an integral calculus class enables the visualization of the abstract concepts of integral calculus through images, video, and animation. The use of these media makes it easy for educators to deliver material so that it can be stored properly in the cognitive structure of students. The use of e-books by educators can facilitate students who have visual and auditory learning styles. For students who prefer the presentation of material through pictures, videos, and animations, the presence of a Hypermedia-based e-Book can help in learning integral calculus material.

The presence of PBL models in integrated calculus aided by Hypermedia-based e-Book can facilitate students who have limitations in remembering various concepts, facts, and procedures because they can learn repeatedly through videos and animations contained in the e-Book. Animation and video presentation of the concepts, facts, and procedures of proving and solving various examples of questions are provided in the e-books. Mampadi, Chen, Ghinea, \& Chen (2011) argue that the use of the Adaptive Hypermedia Learning System in learning influences students' perceptions and performance. 
PBL models in integral calculus courses assisted by the Hypermedia e-Book can increase student productivity, help educators in making effective and efficient learning time, the information provided through e-books is easier to understand and allows learning to be individualized, helping students to learn outside the classroom. or at home. The e-Book containing text, images can be integrated with video and animation so that it is more interactive, and e-Book users will be more interested and can easily understand the contents of the material.

Based on the description above, the focus of the research is (1) a description of the ability to study the results of integral calculus of students who are taught through problembased learning models and the use of hypermedia-based e-books as learning material. Hypermedia-based e-books include elements of text, images, video, and animation, and (2) the effect of the Problem Based Learning model with the help of Hypermedia-based e-books on the learning of integral calculus. The objectives of this research are (1) to describe the students' integral calculus learning outcomes that are taught through problem-based learning models with the help of hypermedia-based e-books, and (1) to examine the effectiveness of the Problem Based Learning Model with the help of Hypermedia-based e-books on calculus learning outcomes integral. The significance of this research are (1) problem-based learning model with the help of Hypermedia-based e-books integral calculus courses are expected to be implemented in students majoring in mathematics education at Halu Oleo University so that the results of learning integral calculus students can be improved, (2) it is expected to increase activities and integral calculus learning outcomes for students of the Department of Mathematics at Halu Oleo University, as reference material for further research that will develop Hypermedia-based learning materials, and (3) Theoretically this research can be useful as a scientific treasure in the field of mathematics education and educational technology.

This study aim is to examine the effectiveness of PBL with the help of hypermedia-based e-books in improving the learning outcomes of students majoring in mathematics at Halu Oleo University. Calculus learning outcomes include the level of memory, understanding, application, analysis, evaluation, and student creativity on integral material and integral application. Hypermedia-based e-book learning materials contain integral calculus materials that integrate elements of text, images, video, and animation. The data were analyzed inferentially through the average difference test.

\section{Method}

The research was quantitative research using experimental methods with a posttest only control design. The research was conducted from February to April 2018. 124 students majoring in mathematics education in the academic year 2017/2018 at Halu Oleo University participated in this study. The sampling was carried out using the Random Sampling Cluster method and obtained two classes consisting of one control class (30) and one experimental class (30). In the experimental class, students were taught with PBL learning models with the help of Hypermedia. Meanwhile, in the control class, traditional learning was conducted with printed teaching materials. The steps of the PBL model include (1) presenting contextual problems, (2) forming cooperative groups, (3) analyzing problems cooperatively, (4) presenting the results of group discussions, (5) reflections. Learning in the experimental class and control class was carried out for eight weeks or eight face-to-face meetings. Furthermore, the instrument used to collect research data was an integral calculus learning achievement test. The research instrument consisted of mathematics learning achievement tests to measure cognitive abilities consisting of memory, understanding, application, analysis, evaluation, and creativity. The instrument used has been validated both theoretically and empirically. Theoretical validity involves an evaluation from expert and mathematics learning experts, while empirical validity is carried out through field trials. Based on the results of theoretical validation by expert evaluation and mathematics learning experts, the mathematical learning outcomes instrument was declared suitable for use. Then the instrument that has been declared worthy was tested on 31 students who have taken integral calculus courses. The trial aims to determine the level of item validity and instrument reliability. 
The instrument trial data were analyzed using the biserial point correlation because the data were discrete and continuous. Based on the instrument validity test, it was found that 25 items were valid and five items were not. To measure the reliability of the mathematics achievement test instrument, the formula of Kuder Ricardson 21 (KR.21) was used. Based on the reliability analysis results of the instrument, the test of learning outcomes was declared reliable with a value of $r_{\text {count }}=0.94$. Based on the analysis of the validity and reliability, the test instrument was declared feasible to be used to collect integral calculus learning outcomes data with a total of 25 items. Furthermore, the instrument was used in the posttest in the experimental class and the control class. Posttest data about learning outcomes in the two classes were then analyzed descriptively and inferentially using the SPSS program. Data analysis techniques consist of descriptive analysis and inferential analysis. The descriptive analysis includes the mean value, variance, and standard deviation, while the inferential analysis includes the normality test, the homogeneity test, and the average difference test.

\section{Results and Discussion}

\subsection{Result}

Description of mathematics learning outcomes in the experimental class and control class can be seen in the following table.

Table 1. Description of Integral Calculus Learning Outcomes in The Experimental Class and The Control Class

\begin{tabular}{cccccc}
\hline & N & Minimum & Maximum & $\begin{array}{c}\text { The } \\
\text { Mean }\end{array}$ & $\begin{array}{c}\text { Std. } \\
\text { Deviation }\end{array}$ \\
\hline $\begin{array}{c}\text { Experimentation } \\
\text { Class }\end{array}$ & 30 & 52.00 & 92.00 & 75.07 & 11.25 \\
Control class & 30 & 44.00 & 84.00 & 65.73 & 10.49 \\
\hline
\end{tabular}

As shown in the table, the minimum value in the experimental class and the control class are 52.00 and 44.00 respectively, while the maximum values are 92.0 and 84.0 respectively. Then the average value of the experimental class and class control are 75.07 and 65.73 respectively, while the standard deviations are 11.25 and 10.49. Based on the average value obtained from both classes, it shows that the average value of integral calculus learning outcomes in the experimental class is higher than the average value of integral calculus learning outcomes in the control class. In the experimental class, many students obtained a value close to or equal to 75.07 to both categories while in the majority of the control class students got close to 65.73 with the medium category.

The results of the inferential analysis in this research are in the form of a normality test, homogeneity test, and average difference test. The normality test results are presented in the following table.

Table 2. Data Normality Test Results Through One-Sample Kolmogorov-Smirnov Test

\begin{tabular}{ccccc}
\hline & $\mathbf{N}$ & Sig (2-tiled) & $\boldsymbol{\alpha}$ & Conclusion \\
\hline Experimentation Class & 30 & 0.87 & 0.05 & Ho received \\
Control Class & 30 & 0.09 & 0.05 & H0 received \\
\hline
\end{tabular}

As shown in the table, the normality test in the experimental class shows that the value of Asymp.sig is $0.877>0.05$. It can be concluded that the learning outcome data in the experimental class come from populations that are normally distributed. Meanwhile, the control class showed that the value of Asymp.sig is $0.09>0.05$. It can be concluded that the learning outcome data in the control class originated from populations that were normally distributed.

Furthermore, the results of the homogeneity test are presented in the following table: 
Table 3. Data Homogeneity Test Results through Levene's Test for Equality of Variance Levene test

\begin{tabular}{|c|c|c|c|}
\hline \multicolumn{2}{|c|}{ Levene's Test For Equality of Variance } & \multirow[t]{2}{*}{$\alpha$} & \multirow[t]{2}{*}{ Conclusion } \\
\hline $\mathrm{F}$ & Sig (2-tiled) & & \\
\hline 0.56 & 0.814 & 0.05 & Ho received \\
\hline
\end{tabular}

As shown in the table, the homogeneity test of learning outcome data in the experimental class and the control class using the Levene test shows the value of sig $=0.814>0.05$. It can be concluded that the class is homogeneous. Then, to examine the effectiveness of the use of PBL on the learning outcomes of integrated calculus assisted by hypermedia-based ebooks, a t-test was conducted. Average difference test results can be seen in the following table:

Table 4. Average Difference Test Results

\begin{tabular}{ccccccc}
\hline & $\mathbf{N}$ & Mean & St.Dev & $\mathbf{t}$ & Df & Sig(1-tailed) \\
\hline Experimentation Class & 30 & 75.07 & 11.25 & \multirow{2}{*}{3.32} & \multirow{2}{*}{58} & 0.001 \\
Control Class & $\mathbf{3 0}$ & $\mathbf{6 5 . 7 3}$ & $\mathbf{1 0 . 4 9}$ & & & \\
\hline
\end{tabular}

As shown in the table, the results of the average difference test with the t-test showed that the value of $\mathrm{sig}=0.001<0.05$ so that $\mathrm{HO}$ was rejected. This means that there is a significant influence of the PBL model with a hypermedia-based ebook on the learning outcomes of the integrated calculus.

\subsection{Discussion}

The results of the study show that descriptively the average learning outcomes of the students 'integral calculus taught through the PBL model were in the high category while the average results of the students' integral calculus learning through the conventional model assisted with printed teaching materials were in the medium category. Moreover, the results of the inferential analysis show that there is a significant effect of the PBL model with the hypermedia-based e-book on learning outcomes of integral calculus. This indicates that the results of integral calculus class who are taught with problem-based learning assisted by the hypermedia-based e-book are better than the results of learning integral calculus taught by traditional methods. Kazemi \& Ghoraishi (2012) state that the Problem Based learning method is more effective than traditional methods in learning mathematics. Kazemi \& Ghoraishi found that PBL affected the attitudes, misconceptions, and performance of mathematics while studying at university although changes in student attitudes were quite slow during the semester influenced by PBL.

Moreover, Yew \& Goh (2016) argue that the stages in PBL affect the learning outcomes of students. Moreover, the results of Gurses, Dogar, \& Geyik, (2015) research show that there are significant differences in academic ability before using PBL and after using PBL. This means that the PBL model can improve students' academic abilities. Gurses, Dogar, \& Geyik only compared the students' academic abilities during the pre-test and post-test while this research compared the students' mathematics learning outcomes in the experimental class and the control class. Although the two studies differed in terms of research design, both studies yielded the same results, namely PBL affected student's learning outcomes. Furthermore, according to Siagian, Saragih, and Sinaga (2019), learning materials that are oriented to problem-based learning can improve students' mathematical and metacognitive problem-solving abilities. Jabarullah and lqbal Husain (2019) argue that the use of PBL models in learning can improve student performance.

The increase in students' integral calculus learning outcomes taught with problem-based learning models is also caused by the implementation of problem-based learning models where students have the opportunity to construct knowledge, concepts, and principles through 
contextual problems. To understand the concept, contextual problems are presented first. These include understanding certain definitions of integrals, problems that are related to the calculation of the area using the inner polygon, outer polygon, and Riemann approaches. Through this method, students find it easier to understand definitions related to certain integrals concept.

Besides that, new knowledge is constructed based on previous knowledge and information obtained from the surrounding environment. Through PBL, students are trained to think analytically to solve problems. This is in line with the results of research by Ar \& Katranc (2014) which shows that PBL can improve students' mathematical thinking skills. Meanwhile, the findings of the present study which applied an experimental design show that PBL can affect students' cognitive processes. it can be seen from aspects of memory, understanding, application, analysis of creativity, and evaluation.

Furthermore, through PBL students become more creative in solving problems (Rahman, 2015). For example, students can determine the volume of solid objects using the ring and tube shell method. Furthermore, PBL facilitates students to work independently and collaboratively in solving given problems so that potential abilities become more enhanced by the presence of his friends as discussion partners in solving problems. Through discussions with colleagues, each student will exchange ideas or ideas to facilitate problem-solving.

Furthermore, through group learning, students are trained to communicate with their group-mates and classmates during a class presentation. Moreover, through cooperative learning in groups, students learn to respect opinions and the diversity that occurs in the group. Each group tries to be the best group among the other groups because in PBL the best group gets appreciation from the lecturer. As a result, each group always tries to solve any given problem correctly, creatively and appropriately and later present to the whole class as well as possible. Group learning also enables students to practice communicating understanding, ideas, or mathematical ideas that are owned and maintain the strategies used in problemsolving. It is training students' self-confidence so they can appear before their peers. Then students learn about strategies used by others. Students learn to accept suggestions from others, convince others so that their opinions can be accepted and convey information in a language that is easily heard and accepted by classmates. This is in line with the opinion of Phungsuk, Viriyavejakul, and Ratanaolarn (2017) that the Problem Based Learning Model can encourage students to learn through participation, practice problem-solving skills, and provide ideas to others in one group. The application of PBL in Phungsuk, Viriyavejakul, and Ratanaolarn's study was supported by virtual environments, while this research was conducted in the form of face to face. Both of the results of this study indicate that PBL can be applied in virtual environments and direct face-to-face learning. The difference is that communication or ideas in a face-to-face environment are conveyed more formally while communication through virtual is informal.

The increase in learning outcomes is also due to the use of hypermedia-based e-book learning materials as a learning resource. Through these materials, students can learn integral calculus material visually through the presence of images, videos, and animations. As a result, their knowledge or their memories becomes long-held in their cognitive structures. The pictures are presented in a hypermedia based e-book as a visualization of a concept in integral calculus material These images cover the image of an antecedent as a linear operator, the image of a family of functions of an anti-derivative, the area of a polygon, the geometrical interpretation of the number of Riemann, the image of an integral calculation by the symmetry method and the periodicity, the image of the function graph above the $x$-axis and below the $x$ axis, the area of rotation over the $x$-axis and the $y$-axis. The pictures are as visualization to make it easier for students to understand the concept of integral calculus relating to antiderivative, area calculations with the approach of polygons inside and outside polygons, integral calculations of course with symmetry methods and methods of periodic properties, calculation of area and volume of rotating objects. The pictures are a semi-concrete representation of an abstract concept. Through the representation of these images, students will easily understand a concept or principle that is being learned. 
The integration of videos in hypermedia-based e-books helps students learn the material repeatedly wherever they are. Through video, students can learn how to prove theorems, implement calculus concepts in calculating the area and volume of solid bodies. It is because the video shows a concept and procedure for solving the problem presented and the video can be seen again following the wishes of the students. Moreover, video learning in e-book allows students to learn integral material repeatedly. Besides that, hypermedia-based e-book also integrates animation. This animation includes the movement of objects falling from a height, animation of sigma notation application for problem solving, animation of calculating the area of a circle with the approach of the inner polygon and outside polygon, animation of calculating the area under the curve $y=x^{2}$ with $x=0$ and $x=3$ through the approach of the inner polygon and outer polygon, the calculation of the volume of a rotating object that surrounds the $x$-axis and the $y$-axis. So the presence of animation of an object that moves enables students to understand the concept of integral applications in calculating the area and volume of objects. The advantage of animation media in integral calculus learning is that concepts learned are stored long in students' memories, make it easy for students to use integral concepts in problem-solving, and remember problem-solving procedures well. The animation media has also made students interested in learning integral calculus.

The students' integral calculus learning outcomes on the cognitive aspects after using a Hypermedia - based e-Book increased significantly because students were motivated and had learning independence. Learning outcomes in these cognitive aspects include memory, understanding, application, analysis, evaluation, and creativity. The results of the study show that students can remember facts or symbols, mathematical formulas, definitions, and theorems. For example, students can write anti-derivative definitions and write basic calculus theorems about solving certain integrals. Students can interpret mathematical problems, i.e. students can identify what is known, what is asked from the given problem. Then students can apply mathematical problem-solving procedures appropriately. For example, students can complete the area under the curve with the polygon approach through the steps of partition, approach, add up, and determine the limit. In the partitioning step, the student can make interval partitions $[a, b]$ to $n$ section intervals to determine the interval points of the section intervals. In the approaching step, the student approaches the area under the curve by taking a certain rectangle from the partition to determine the area of the approximation. Then students add up the results of the partition to $\mathrm{n}$ part of the partition. After that, students determine the limit of that number when $n$ goes to infinity. In solving problems students have various strategies, for example, determining the area under the curve by using the approach of the polygon inside or outside polygon and determining the volume of a rotating object that can be done by the method of discs, tubes or rings. Besides that, students can solve problems smoothly and precisely. Students can clarify that the strategies have been used appropriately. The ability to analyze problems also shows good results. For example, when students are given contextual problems related to the determination of the area, students can make mathematical models as a basis for solving these problems. It is because problem-basedlearning students are trained to analyze contextual problems.

Moreover, students have the motivation to solve mathematical problems. This motivation includes the desire to work on practice questions, ask questions to the lecturer, the ability to work with a group of friends, participation in class discussions. Students can use learning materials in the form of hypermedia. Learning independence is also demonstrated through the ability to explore subject matter in the form of hypermedia. Moreover, students have a good initiative to work on practice questions and show some courage to present problem-solving strategies. Indications of student learning independence are also seen when planning various strategies in solving integral problems. Students are confident to utilize the potential possessed in solving the problem of integral calculus. This is in line with the opinion of Moos \& Marroquin, (2010); Taub, Azevedo, Bouchet, \& Khosravifar (201 4), Hypermedia components can present information from various directions either through text, images, animation or video so that students are motivated to learn, and have self-regulated learning when using learning-based resources. hypermedia. A research conducted by Moos \& Marroquin examining the effect of the use of multimedia, hypermedia, and hyperlinks on 
motivation using literature synthesis indicates that there is an influence of the use of multimedia, hypermedia, and hyperlinks on learning motivation. Moreover, Taub, et al, who examined the effect of the Self-Regulated Learning Strategy in a hypermedia environment on students' prior knowledge and interaction, found that the hypermedia environment and the use of learning independence strategies could influence the initial knowledge and interaction of students in learning. In contrast, the results of this study show that there is an effect of the PBL model with the help of e-book-hypermedia on learning outcomes.

Moreover, according to Güyer (2009); (Fan, 2012); Winne \& Nesbit, (2010); Zimmerman, (2002 in Paans et al., 2018); Mampadi, Chen, Ghinea, \& Chen (2011); and Lugli, Ragni, Piccardi, \& Nori (2017): state that the use of hypermedia as a source of learning can affect perceptions, performance and can facilitate learners' learning styles and cognitive styles. When students learn by using hypermedia elements, students with visual learning styles will easily understand the subject matter. This is caused by the material presented visually using images, video, or animation. This course will also attract students' interest and attention while studying. For students who have an auditory learning style, they are also accommodated through hypermedia elements. Students will listen to a detailed explanation of the concepts being learned, how to solve problems, and be able to listen repeatedly. The use of hypermedia elements in integral calculus class can improve metacognitive abilities and learning independence. This is in line with Opfermann, Scheiter, Gerjets, and Schmeck (2013) stating that the hypermedia environment can also support metacognitive abilities and skills and organize themselves. Students not only receive information but must make decisions about the learning process.

\section{Conclusion and Recommendation}

\subsection{Conclusion}

Based on the results of research and discussion, it can be concluded that (1) the description of the ability of learning outcomes of students in integral calculus who are taught through problem-based learning models with the help of hypermedia-based e-books is in the high category while the learning outcomes of students' integral calculus taught through conventional models with the help of printed teaching materials are in a low category, and (2) Integral calculus learning outcomes that are taught with problem-based learning models with the help of hypermedia-based e-books are significantly better than integral calculus learning outcomes taught through conventional learning models assisted with printed teaching materials.

\subsection{Recommendation}

The results of the study showed that there was an effect of the use of PBL learning models on integral calculus learning outcomes. Therefore, it is expected that lecturers can use the PBL model in integral calculus learning so that learning outcomes can be achieved. Moreover, integral calculus lecturers can develop and use hypermedia-based e-books as learning resources and learning media for integral calculus making it easier for students to learn integral calculus material.

\section{References}

Ahmad, R., \& Bayat, S. (2012). Collaborative problem-based learning in mathematics: A cognitive load perspective, 32(2011), 344-350. https://doi.org/10.1016/j.sbspro.2012.01.051

Ar, A. A., \& Katranc, Y. (2014). The opinions of primary mathematics student-teachers on the problem- based learning method, 116(5), 1826-1831. https://doi.org/10.1016/j.sbspro.2014.01.478

Balan, L., Yuen, T., \& Mehrtash, M. (2019). ScienceDirect ScienceDirect ScienceDirect ScienceDirect Problem-Based Problem-Based Learning Learning Strategy Strategy for CAD CAD Software Software Using Using Free- Choice and Open-Ended Group Projects Choice and Open-Ended Group Projects Costing $\mathrm{m}$. https://doi.org/10.1016/j.promfg.2019.02.223 
Fan, W. (2012). An experimental comparison of the flexibility in the use of thinking styles in traditional and hypermedia learning environments, 7, 224-233. https://doi.org/10.1016/j.tsc.2012.04.007

Gerjets, P. (2017) Learning and Problem-Solving with Hypermedia in the Twenty-First Century: From Hypertext to Multiple Web Sources and Multimodal Adaptivity. In: Schwan S., Cress U. (eds) The Psychology of Digital Learning. Springer, Cham.

Gonźalez, J. C., Guzman, J. L., Dormido, S., \& Berenguel, M. (2013). Development of interactive books for control education. In IFAC Proceedings Volumes (IFACPapersOnline). https://doi.org/10.3182/20130828-3-UK-2039.00043

Gurses, A., Dogar, C., \& Geyik, E. (2015). Teaching Of The Concept Of Enthalpy Using Problem Based Learning Approach. Procedia - Social and Behavioral Sciences, 197(February), 2390-2394. https://doi.org/10.1016/j.sbspro.2015.07.298

Güyer, T. (2009). Computers \& Education The measures weighted stratum and weighted compactness on the weighted digraph-based models of the hypermedia and navigation. $\begin{array}{llll}\text { Computers \& Education, 53(2), 252-260. } & \text { 2 }\end{array}$ https://doi.org/10.1016/j.compedu.2009.02.004

Izzati, N., Ahmad, R., \& Abu, R. (2010). The Effects of Problem Based Learning on Mathematics Performance and Affective Attributes in Learning Statistics at Form Four Secondary Level, 8(5), 370-376. https://doi.org/10.1016/j.sbspro.2010.12.052

Jabarullah, N. and lqbal Hussain, H. (2019), "The effectiveness of problem-based learning in technical and vocational education in Malaysia", Education + Training, Vol. 61 No. 5, pp. 552-567. https://doi.org/10.1108/ET-06-2018-0129

Kazemi, F., \& Ghoraishi, M. (2012). Comparison of Problem-based Learning Approach and traditional teaching on attitude, misconceptions and mathematics performance of University Students, 46, 3852-3856. https://doi.org/10.1016/j.sbspro.2012.06.159

Lugli, L., Ragni, M., Piccardi, L., \& Nori, R. (2017). Computers in Human Behavior Hypermedia navigation: Differences between spatial cognitive styles, 66, 191-200. https://doi.org/10.1016/j.chb.2016.09.038

Maadi, F., Chen, S. Y., Ghinea, G., \& Chen, M. (2011). Computers \& Education Design of adaptive hypermedia learning systems: A cognitive style approach. Computers \& Education, 56(4), 1003-1011. https://doi.org/10.1016/j.compedu.2010.11.018

Monica, L., Gorghiu, G., Bîzoi, M., \& Marra, A. (2011). Procedia Computer The Electronic Book - a Modern Instrument Used in Teachers ' Training Process. Procedia Computer Science, 3, 563-567. https://doi.org/10.1016/j.procs.2010.12.093

Moos, D. C., \& Marroquin, E. (2010). Computers in Human Behavior Multimedia, hypermedia, and hypertext : Motivation considered and reconsidered. Computers in Human Behavior, 26(3), 265-276. https://doi.org/10.1016/j.chb.2009.11.004

Opfermann M., Scheiter K., Gerjets P., Schmeck A. (2013) Hypermedia and Self-Regulation: An Interplay in Both Directions. In: Azevedo R., Aleven V. (eds) International Handbook of Metacognition and Learning Technologies. Springer International Handbooks of Education, vol 28. Springer, New York, NY

Paans, C., Molenaar, I., Segers, E., \& Verhoeven, L. (2018). Temporal variation in children's self-regulated hypermedia learning. Computers in Human Behavior. https://doi.org/10.1016/j.chb.2018.04.002

Pérez-Torregrosa, A. B., Díaz-martín, C., \& Ibáñez-cubillas, P. (2017). The use of Video annotation tools in teacher training, 237(June 2016), 458-464. https://doi.org/10.1016/j.sbspro.2017.02.090

Phungsuk, R., Viriyavejakul, C., and Ratanaolarn, T. (2017). Development of a problembased learning model via a virtual learning environment. Kasetsart Journal of Social Sciences xxx (2017) 1-10. http://dx.doi.org/10.1016/j.kjss.2017.01.001

Rowhani, S. \& Sedig, K. (2005). E-books plus: Role of interactive visuals inexploration of mathematical information and e-learning. Journal of Computers inMathematics and Science Teaching, 24(3), 273-298. Norfolk, VA: Association for theAdvancement of Computing in Education (AACE). Retrieved July 26, 2018 
Savery, J. and Duffy, T. (1995), "Problem-based Learning: An instructional model and its constructivist framework," Educational Technology, 35(5), 35, 1995.

Siagian, M.V., Saragih, Sahat., Dan Sinaga, B. (2019). Development Of Learning Materials Oriented On Problem-Basedlearning Model To Improve Students' Mathematical Problemsolving Ability And Metacognition Ability, Nternationalelectronicjournalofmathematicseducatione.

Sinprakob, Surasak and Songkram, Noawanit (2015). A proposed model of problem-based learning on social media in cooperation with searching technique to enhance critical thinking of undergraduate students. Procedia - Social and Behavioral Sciences 174 ( 2015 ) $2027-2030$.

Steinke, M., Huk, T. \& Floto, C. (2004). The Influence of Cognitive Abilities and the Presence of 3D Models on the Use of Task Relevant Content in Hypermedia Learning Systems. In L. Cantoni \& C. McLoughlin (Eds.), Proceedings of ED-MEDIA 2004--World Conference on Educational Multimedia, Hypermedia \& Telecommunications (pp. 19371942). Lugano, Switzerland: Association for the Advancement of Computing in Education (AACE). Retrieved March 11, 2020 from https://www.learntechlib.org/primary/p/12746/.

Taub, M., Azevedo, R., Bouchet, F., \& Khosravifar, B. (2014). Computers in Human Behavior Can the use of cognitive and metacognitive self-regulated learning strategies be predicted by learners ' levels of prior knowledge in hypermedia-learning environments? COMPUTERS IN HUMAN BEHAVIOR, 39, 356-367. https://doi.org/10.1016/j.chb.2014.07.018

Wijnia, et al. (2014). "Is there a role for direct instruction in problem-based learning? Comparing student-constructed versus integrated model answers", journal homepage: Learning and Instruction 34 (2014), www.elsevier.com/locate/learninstruc.

Yew, E. H. J., \& Goh, K. (2016). Problem-Based Learning : An Overview of its Process and Impact on Learning, 2, 75-79. https://doi.org/10.1016/j.hpe.2016.01.004 